\title{
MIR375 Gene
}

National Cancer Institute

\section{Source}

National Cancer Institute. MIR375 Gene. NCI Thesaurus. Code C101664.

This gene plays a role in gene silencing. 